\title{
Simulation role play as a contact work with students and its role in their communicative skills development
}

\author{
Anna Korochentseva ${ }^{1,{ }^{*}, \text { Evgenia Krasnova, Olga Moysova }}{ }^{1}$ \\ ${ }^{1}$ Don State Technical University, Gagarina sq. 1, 344000 Rostov-on-Don, Russia
}

\begin{abstract}
The article describes the diagnostic and correctional possibilities of using simulation role play with University students. It should be noted, that simulation and a role play allows to immerse students in active controlled communication, where they can express themselves, learn about their hidden capabilities, and develop their skills necessary for more productive functioning as a group or individually. Such play should contain elements of modeling, construction, and transformation. Today, simulation role play offers great opportunities to work with any categories of students, and have a great practical use, as it provides an opportunity to master both verbal and non-verbal forms of communication in various situations, clearly demonstrating the ways and possibilities to apply in practice the knowledge gained.The study showed that the use of simulation role play in the educational process helps to increase significantly the communicative competence of students. Thanks to a 4 months' simulation role play with students during their studies at the University, they have significantly increased their communication competence, formed new communication skills and communication behavior strategies, and decreased the indicators of "communicative clumsiness". The results suggest that simulation role play as a type of socio-psychological training can be actively used in teaching practice at the University for the development of students ' communication skills, as it involves dialogue, relying on life experience and feelings of younger generation. This is a form of specially organized communication, which may become necessary in the increasing distant "indirect interaction" in our lives through social networks and the Internet.
\end{abstract}

\section{Introduction}

The world is changing so fast that people do not have time to adapt to the changes they have made. People's well-being is endangered and threatened. And one of these dangers for modern youth is inability to communicate, to conduct interpersonal communication. This is due to their constant involvement in "indirect communication", they communicate a lot in social networks, play computer games, and are included in various social groups organized on the Internet $[4,22,29]$. All these factors reduce to a minimum the possibility of real "live" communication among young people. Which is necessary for the development of personality

\footnotetext{
* Corresponding author: anna-kor@bk.ru
} 
and the establishment of full-fledged interpersonal relationships between peers [18]. As a result, we get a generation of people with poorly developed communication competence, which have difficulties in establishing interpersonal contacts, and do not have the skills to present themselves effectively in business or personal relationships. In this regard, even those children who seem to be effective communicators are unable to turn them into abilities.

Simulation role play is an artificially created life or problem situation that we reproduce, transferring the real life problem into the game activity [7, 20, 27], and today, it can be considered one of the main means of developing communication skills [17, 19]. Various types of trainings and business games are the most productive forms of working with youth groups [16]. They create an "eco-friendly" atmosphere that allows you to "try yourself" in various situations of interpersonal interaction, work out unresolved problems, and develop constructive forms of interpersonal and intra-group interaction [21, 28]. Within the simulation role play it becomes possible to immerse young people in active controlled communication, where they can express themselves, learn about their hidden capabilities, discover new ones, and develop skills necessary for more productive functioning in society $[5,9,14]$. Research shows that the use of game methods in training gives better results than the use of case methods [25, 26].

Simulation role play discover problems in dynamics, allow participants to live dozens of imaginary years shortened by time and events [24]. You can fly into space, find yourself on an island full of unpredictable foreigners, run for politics, etc. $[4,12,15]$. During the play, each participant makes mistakes and finds successful solutions, enriching personal experience that is not forgotten, because "it happened to me". As a result of such classroom playing participants understand universal values, develop imagination, and acquire skills to participate in discussions and make collective decisions in various situations being a part of a changing system [3].

The most productive dealing with the development of social communicative competence and correction of unproductive behaviors in the student environment are games and exercises aimed at developing creative, and most important, joint solutions to various problems in which in order to come to a "common denominator" it is necessary to communicate, convince, interact with one another [13]. Such games should contain elements of modeling, construction, and transformation [23]. Games may require the following materials: paints, brushes, pencils, markers, crayons, glue, scissors, newspapers, magazines, a tape recorder, various audio recordings, musical instruments, costumes or their elements, body paints or makeup, wigs, mirrors, etc. Thus, in our opinion, simulation role play is one of the most promising methods for developing students ' communication and interaction skills.

Domestic researchers note that such training technology - simulation role play - is a type of activity aimed at recreating, assimilating and transmitting social experience, in which behavior self-management is formed and improved, as well as the possibility of trying various professional, social and other roles [2]. Simulation role play helps to create an atmosphere of communication, it unites participants, creates new emotional and communicative relationships between them, based on effective interaction [4].

In imitation-role-playing games, psychological training of effective interaction is carried out, negative behaviors and emotional manifestations of the individual are corrected, and at the same time self-presentation skills are developed. Another advantage is that in the simulation role-play participants have the opportunity to choose a role that will allow them to visit an unusual situation for them, and perhaps they will be surprised by the sides of their personality that have opened up for them, their own abilities and skills. The proposed role should help each participant strengthen their authority among students, become organized, consistent in their actions, develop self-control, and the ability to navigate role positions and communication situations [2]. 
The simulation role play has great diagnostic abilities. As soon as the participants start discussing the tasks set, they show their communication skills, the leader appears, and such qualities as persistence/compliance, flexibility, self-determinedness, the desire to be in the center or the desire to be invisible are revealed. All this is put down by the trainer according to the selected parameters. Communication and leadership skills are especially well diagnosed, such participants strive to unite others around them, try to negotiate and reach mutual agreements.

Gerasimova N. I. defines simulation role play as a psychological-pedagogical and didactic-technological phenomenon of recreating the subject and social content of future professional activity, modeling systems of relations typical for a specific corporate culture [8].

Simulation role play is a technology based on group interaction based on the personal practical experience of participants [9]. The experience gained by students in the playing interaction can be even more productive in comparison with the acquired one in professional activities. This happens for several reasons. Firstly, simulation role play allow you to increase the scope of reality, clearly represent the consequences of the decisions made, give you the opportunity to test alternative solutions and try on certain social roles. Secondly, the information that a person uses in reality is in most cases incomplete, distorted, while playing they are provided with incomplete but accurate information, which increases confidence in the results obtained and stimulates the process of accepting responsibility [1].

In practice while studying at the University, you can use various types of game interaction. In our opinion, one of the most rational technologies for organizing such interaction of students, which involves dialogue, relying on the life experience and the sphere of feelings of the younger generation, is an simulation role play as a type of sociopsychological training. This is a form of specially organized communication, the psychological impact of which is based on active methods of group work [11].

Various types of training are used in the practice of professional training. Communication trainings on the development of verbal and non-verbal competence of trainees, their interactive skills and abilities are more effective in training specialists. Communication training also includes behavioral training, i.e. training of skills within the business behavior, telephone communication, and leadership skills [8]. At the same time, the most important point in this process is the immersion of participants in various social roles. $\mathrm{O} . \mathrm{N}$. Bogdanovich notes that a role play can be social (determined by the individual's place in the system of objective social relations: professional, socio-demographic) and interpersonal (determined by the individual's place in the system of interpersonal relations: leader, friend, rival) [10]. Participants get the most productive results when they are in roles that they have never performed in real life. As a result, they develop new skills that were not previously familiar or used [13].

Simulation role play is of great interest for students at different stages of training, and of great practical use, as it is an opportunity to master both verbal and non-verbal forms of communication in various situations, clearly demonstrating the ways and possibilities of practical application of the knowledge gained. The success of the simulation role play largely depends on the regular bases of such type of work and age. The earlier you start developing social communication, the higher the readiness for it [1]. If a student gets the opportunity to be in such an environment that is favorable for the development of social and communicative activity, which contributes to the skills of productive communication and interaction, his life, both personal and business, can be much more successful, in whatever field he would work.

Thus, the purpose of our research is to study the features of using simulation role play as a way to develop students ' communicative competence. 


\section{Research methods}

The research was made in three stages.

At the first stage, to determine the level of development of students ' communicative and organizational aptitudes, we used the method of "Assessment of communicative and organizational aptitudes (COA)" by B. A. Fedorishin [14], and test "Communication skills" developed by L. Mikhelson [14]. As a result, we got two estimated communication and organizational aptitude coefficients, as well as an indicator of communication skills.

Further on, to determine the assessment of students 'social and communicative competence, we used a test questionnaire: "Assessment of social and communicative competence" [14]. This test questionnaire allowed us to determine the ability to establish and maintain the necessary contacts, make our own decisions, and work in a team. The test of social and communicative competence allowed us to determine the severity of various personality characteristics of the subjects on eight scales. In particular, it showed the students ' desire to work in a team (or lack of it), the development of logical thinking, the tendency to make decisions independently or focus on the group. Each of the respondents was offered a questionnaire that included statements about their behavior, habits, and views. After that, to determine the level of sociability, all respondents were presented with the method "Sociability level assessment", developed by V. F. Ryakhovsky [14].

The next stage of the study included conducting simulation role play with students. Simulation role play has been held with students for several months, as part of practical classes in psychology.

Most simulation role play were aimed at: improving the psychological climate in groups, increasing cohesion, developing communication skills, listening to each other, negotiating and making group decisions. Simulation role play was characterized by the presence of a task or problem and the distribution of roles between the participants to solve it, and represented a simulation of real mechanisms and processes.

Each simulation role play included several stages: 1) introducing the theme; 2) introducing the scenario, tasks and roles; 3) supporting the play process (the teacher's task was to monitor compliance with the play rules, explain some important points, and facilitate interaction if necessary); 4) analyzing the completed simulation (it was necessary to help students compare what was happening with the realities, with their life experience).

At the third stage of the research, a repeated (final) study was made by using all the mentioned methods. Also at this stage of the study, we conducted a comparative analysis of the results of preliminary and final testing and determined the significance of differences between all indicators using a mathematical procedure such as: Wilcoxon Z-test.

Several types of games were held: Organizational and activity games (OAG - to "make" the group a unit of the educational process, but on condition of preserving the personal position. Role play that is characterized by the presence of a task or problem and the distribution of roles between participants for its solution. Business games that are simulations of real mechanisms and processes. Cognitive-didactic games that create situations characterized by including the subject in an unusual game context.

The empirical object of the study was 75 students of technical specialties of the Don State Technical University, from 16 to 18 years old (40 boys, 35 girls).

The reliability of the obtained data was ensured using a mathematical procedure such as the Wilcoxon Z-test, using the computer program "SPSS 23.0 for Windows".

\section{Results}

Significant differences were found in the expression of students ' communication skills before and after using simulation role play. According to the results of the final testing, the indicators 
of communication and organizational skills were significantly higher compared to the preliminary testing. On the scale of " Communication skills " $(Z=5.069)$ and on the scale of "Organizational skills " $(Z=3.927)$. At the same time, simulation role play had a greater impact on changes in communication skills compared to organizational skills. This suggests that simulation role play is the most effective in the development of communication skills, and the development of new strategies of behavior in communication.

Michelson test of communication skills showed that the severity of dependence and aggressiveness of students after using simulation role play decreased. This is indicated by changes in the scales of communication skills "Dependent " and "Aggressive". This means that students were able to develop such skills as providing and accepting signs of attention to their peers, the ability to turn to a fellow student with a request for help and at the same time feel confident, the ability to sympathize with another person. At the same time, competence in communication became significantly higher in comparison with the results of preliminary testing (an indicator of the significance of differences between preliminary and final testing after using simulation role play on the "Competent" scale $(Z=2,760))$.

Next, we analyzed the results obtained using the test questionnaire for assessing "social and communicative competence".

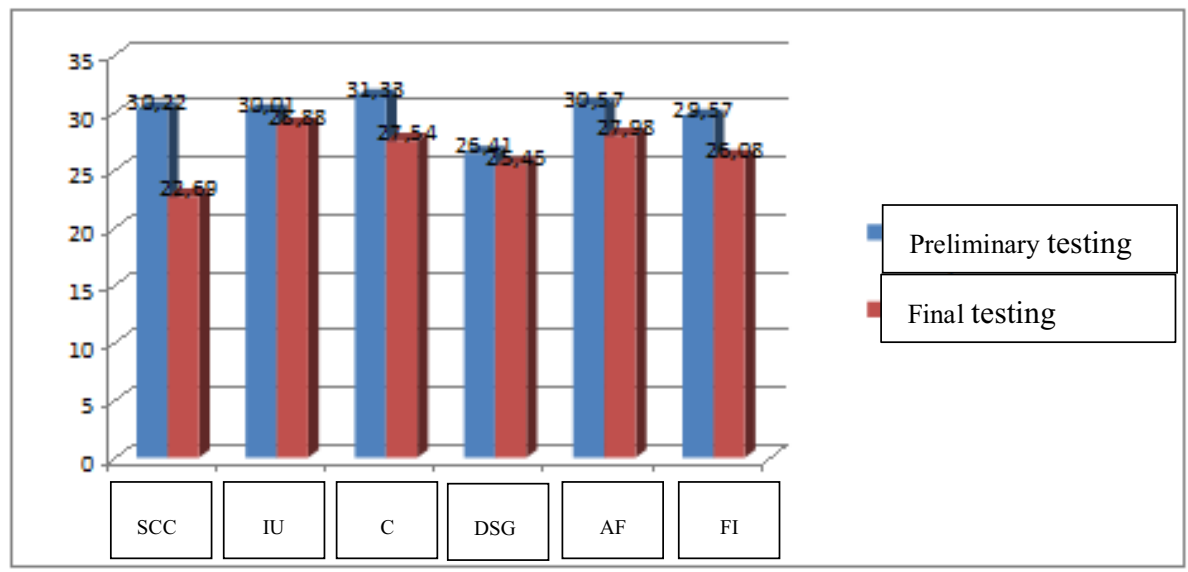

Fig. 1. Communicative social competence indicators.

Figure 1 shows that the indicators of communicative social competence on the scales: "Social and communicative clumsiness(SCC)", "Intolerance to uncertainty(IU)", "Excessive desire for conformity(C)", "Increased desire for status growth(DSG)", "orientation to avoid failures(AF)", "Frustration intolerance(FI)" according to the final results decreased.

Statistically significant differences were found on the scale of "Social and communicative clumsiness" $(Z=3.032)$. After performing simulation role play, "Social and communicative clumsiness" was significantly lower than the results of preliminary testing. These data indicate that communication skills have undergone positive changes, students have become less "clumsy" in establishing communication contacts and behavior in a communicative environment, and they have become more tolerant to interlocutors.

Furthermore, a comparative analysis of sociability level was carried out.

After simulation role play the overall level of sociability was significantly higher than the results obtained from preliminary testing (Z-criterion 3,742). Students with the help of simulation role play found new techniques for self-development and self-discovery, created a favorable climate in the group and learned not to pay attention to offending, provoking behavior on the part of peers. 


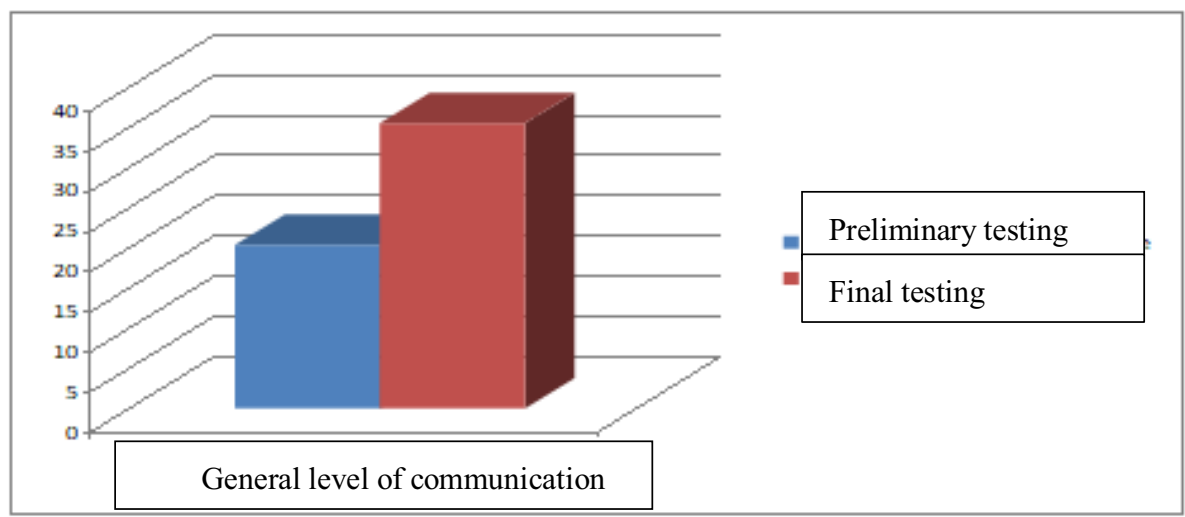

Fig. 2. Sociability level indicators.

\section{Discussion}

As a result of the simulation role play the indicators of communication skills became significantly higher compared to the preliminary testing. This means that students have developed the ability to speak in front of an audience without fear, found friends, found the desire to expand their circle of acquaintances, began to take the initiative in communicating with fellow students and teachers, strive to be engaged in social activities, and make decisions independently in difficult situations. It was interesting that simulation role play had a greater impact on changes in communication skills compared to organizational skills. This suggests that simulation role play is the most effective in the development of communication skills, and the development of new strategies of behavior in communication.

The biggest changes in the process of simulation role play have happened to specific scales of communication skills. These are the scales of "Dependence" and "Aggressiveness", "Social and communicative clumsiness", students began to understand better their psychological state and react more calmly to the behavior of other participants in the interaction process, and increased their communicative competence in communication.

In general, the use of interactive technologies has found great interest among students, as they allow deep and multidimensional consideration of a large range of problems; they teach "through action", organize social interaction and prepare for constructive professional communication. Classes with students in a playful way contributes to greater activity for interaction of participants in the learning process, they are rich in meaningful and multifaceted feedback, form value orientations and attitudes of professional activity, provide an opportunity for comprehensive analysis, interpretation, comprehension of the results; contribute to the manifestation of all personal qualities and individual characteristics.

\section{Conclusions}

Significant differences were found in the expression of students ' organizational skills before and after using simulation role play. According to the results of the final testing, the indicators of organizational skills were significantly higher compared to the preliminary testing. This means that as a result of using simulation role play students during one semester developed the ability to correctly, competently and clearly explain their thoughts and adequately perceive information from communication partners, make and analyze independent decisions, defend their opinion and ensure that it was accepted by their friends. 
According to the results of the final testing, students ' indicators on the "Dependent" and "Aggressive" scales decreased after using simulation role play. This means that students were able to develop such skills as providing and accepting signs of attention to their peers, the ability to turn to a fellow student with a request for help and at the same time feel confident, the ability to sympathize with another person. Students have developed the ability to respond adequately to fair criticism, not to pay attention to offensive, provocative behavior on the part of their peers.

Significant differences were found in the expression of communication skills measured before and after simulation role play on the "Competent" scale. This means that students have become more active in trying to involve themselves in social activities, have learned to navigate quickly in difficult situations, they are at ease in a new team, they are proactive, prefer to make independent decisions in an important matter or in a difficult situation, defend their opinion and make sure that it is accepted by their friends.

Significant differences were found in the expression of such a parameter of social and communicative competence as "social and communicative clumsiness" of students before and after the use of simulation role play. The results of the final testing show that "Social and communicative clumsiness" decreased in comparison with the preliminary testing. In other words, communication skills have come throw positive changes, students have become less "clumsy" in establishing communication contacts and behavior in a communicative environment, they have learned to show and accept signs of attention, to respond adequately to fair criticism, and not to pay attention to offending, provoking behavior on the part of peers.

Significant differences were found in the level of sociability of students before and after the use of simulation role play. According to the results of the final testing, the overall level of sociability was significantly higher than the results of the preliminary testing. Students with the help of simulation role play found new techniques for self-development and selfdiscovery, created a favorable climate in the group and learned not to pay attention to offending, provoking behavior on the part of peers.

\section{References}

1. L.N. Kononyhina, D.A. Matveeva, T.N. Kozlyak, N.V. CHernikova, Sbornik nauchnyh trudov po materialam Mezhdunarodnoj nauchno-prakticheskoj konferencii (Belgorod, 2018) https://www.elibrary.ru/item.asp?id=32283154

2. D.V. Zhislina, A.S. Pasechnik, V.A. Demarin, K.S. Gordeev, Sbornik statej po materialam XV Mezhdunarodnoj nauchno-prakticheskoj konferencii prepodavatelej, uchenyh, specialistov, aspirantov, studentov (Nizhegorodskij gosudarstvennyj pedagogicheskij universitet imeni Koz'my Minina, 2017) https://www.elibrary.ru/item.asp?id=32697041

3. E.V. Bityuckaya, D.N. Kavtaradze, Vestnik Moskovskogo universiteta. Seriya 14: Psihologiya 3, 3-26 (2019) doi: 10.11621/vsp.2019.03.03

4. A.V. Korochenceva, E.V. Carevich, Materialy nacional'noj nauchno-prakticheskoj konferencii "Aktual'nye problemy nauki $i$ tekhniki», 1068-1069 (2019) https://www.elibrary.ru/item.asp?id=37285531

5. J.I. Fedorova, Igra: didakticheskaya, rolevaya, delovaya. Reshenie uchebnyh I professional'nyh problem (FORUM, Moscow, 2009) https://www.elibrary.ru/item.asp?id=20056941

6. G.M. Chudajkina, N.Y. Loginova, V.V. Kostovarova, Vestnik Associacii vuzov turizma i servisa 4(11), 82-92 (2017) doi: 10.22412/1999-5644-11-4-11 
7. N.N. Anikeeva, Vospitanie igroj (Prosveshchenie, Moscow, 1987) https://search.rsl.ru/ru/record/01001353918

8. N.I. Gerasimova, Delovaya igra kak interaktivnyj metod obucheniya rechevoj deyatel'nosti. Srednee professional'noe obrazovanie (Izdatel'stvo «SPO», Moscow, 2011) https://www.elibrary.ru/item.asp?id=15588050

9. A.E. Cyrendorzhiev, Vestnik buryatskogo gosudarstvennogo universiteta izdatel'stvo: Buryatskij gosudarstvennyj universitet imeni Dorzhi Banzarova 1, 30-36 (2018) doi: 10.18101/1994-0866-2018-1-1-30-36

10. O.N. Bogdanovich, Sovremennye formy organizacii uchebno-vospitatel'nogo processa: prakticheskoe posobie dlya pedagogov obshcheobrazovatel'nyh uchrezhdenij (Belyj veter, Mozyr', 2009) https://e-catalog.nlb.by/Record/BY-NLB-br0000253068

11. I.G. Yakimovich, Vestnik Bryanskogo gosudarstvennogo universiteta 1(27), 381-383 (2016) https://www.elibrary.ru/item.asp?id=32283154

12. C.H. Cherryholmes, American Behavioral Scientist 10(2), 4-7 (1966) doi: 10.1177/000276426601000202

13. A.C. Burns, J.W. Gentry, Simulation and Gaming 29, 133-151 (1998) doi: $10.1177 / 1046878198292001$

14. Social and psychological diagnostics of personality development and small groups (Publishing house Of the Institute of Psychotherapy, Moscow, 2009) ISBN 978-5903182-45-9 https://www.elibrary.ru/item.asp?id=20100884\&

15. K.O. Jensen, BT Technology Journal 21(2), 133-144 (2003) doi: 10.1023/A:1024407506021

16. B. Keys, J. Wolfe, Journal of Management 16(2), 307-336 (1990) doi: 10.1177/014920639001600205

17. A.B. Hernández-Lara, A. Perera-Lluna, E. Serradell-López, Computers in Human Behavior 92, 600-612 (2019) doi: 10.1016/j.chb.2018.03.001

18. J. Hyppa-Martin, J. Reichle, American Journal of Speech-Language Pathology 27(2), 657-671 (2018) doi: 10.1044/2017_AJSLP-16-0242

19. A.B. Hernández-Lara, E. Serradell-López, Behaviour and Information, Technology 37(4.3), 419-429 (2018) doi: 10.1080/0144929X.2018.1441326

20. A.B. Hernández-Lara, E. Serradell-López, Computers in Human Behavior 101, 311-319 (2019) DOI: 10.1016/j.chb.2019.07.023

21. D. Eseryel, V. Law, X. Ge, R. Miller, Educational Technology and Society 17(1), 42-53 (2013)

https://www.scopus.com/record/display.uri?eid=2-s2.084878111924\&origin=reflist\&sort=plf-f\&src=s\&sid

22. V.I. Pishchik, G.A. Molokhina, E.A. Petrenko, Y.V. Milova, International Journal of Cognitive Research in Science, Engineering and Education (IJCRSEE) 7(2), 67-76 (2019) https://doi.org/10.5937/IJCRSEE1902067P

23. J. Ardies, S. De Maeyer, D. Gijbels, H. van Keulen, International Journal of Technology and Design Education 25(1), 43-65 (2014) doi: 10.1007/s10798-014-9268-X

24. A.J. Faria, Simulation and Gaming 28(4), 360-376 (1997) doi: $10.1177 / 104687810103200108$

25. J. Wolfe, Simulation and Gaming 28(4), 360-376 (1997) doi: $10.1177 / 1046878197284003$

26. E. Hsu, Simulation \& Gaming 20(4), 409-438 (1989) DOI: $10.1177 / 104687818902000402$ 
27. F.G. Boseman, R.E. Schellenberger, Simulation \& Gaming 5(4), 383-402 (1974) doi: $10.1177 / 104687817400500403$

28. W.H. Starbuck, E. Kobrow, Behavioral Scientist 10(3), 28-30 (1966) doi: $10.1177 / 000276426601000305$

29. A. Masood, Y. Feng, A. Luqman, A. Ali, Explaining underlying mechanism from stress perspective 113, 106476 (2020) doi: 10.1016/j.chb.2020.106476 